\title{
PERLINDUNGAN POTRET UNTUK PROMOSI TANPA IZIN PIHAK TERKAIT BERDASARKAN UNDANG-UNDANG NOMOR 28 TAHUN 2014
}

\author{
Oleh: \\ Nurtati Dwika ${ }^{1)}$, \\ Emmi Siregar ${ }^{2}$, \\ dan Irda Pratiwi ${ }^{3)}$ \\ Universitas Asahan 1,2,3) \\ E-mail: \\ dwisuju48@gmail.com ${ }^{1)}$, \\ ramiwita_nst@ymail.com ${ }^{2}$, \\ dan irdanasty@ymail.com ${ }^{3}$
}

\begin{abstract}
Portraits are photography work with human objects and the portrait itself is regulated by copyright law. If a portrait is taken without the consent of the photographed, the photographer will be subject to law number 28 of 2014. if the portrait is used for promotion or published without the must permission of the photographer or the heir, the photographer must first ask permission of the photographer. If the photographer does not have permission to the photographed or the heirs to carry out commercial uses, procurement, distribution, etc., will be subject to article 115 of law number 28 of 2014 concerning copyright. The photographer will be charged with a maximum fine of IDR 500.000.000,00 (five hundred million rupiah). It would be better if a photographer who would take someone's portrait for promotion, asks permission of the portrait or ask permission from the heirs first.
\end{abstract}

Keywords: portrait copyrighted works, legal protection, law no 28 of 2014.

\begin{abstract}
ABSTRAK
Potret adalah karya fotografi dengan objek manusia dan potret itu sendiri diatur oleh undang-undang hak cipta. Jika potret diambil tanpa persetujuan dari yang difoto, fotografer akan tunduk pada undang-undang nomor 28 tahun 2014. jika potret tersebut digunakan untuk promosi atau diterbitkan tanpa izin dari fotografer atau ahli waris, fotografer harus terlebih dahulu meminta izin fotografer. Jika fotografer tidak memiliki izin untuk difoto atau ahli waris untuk melakukan penggunaan komersial, pengadaan, distribusi, dll., Akan tunduk pada pasal 115 undang-undang nomor 28 tahun 2014 tentang hak cipta. Fotografer akan dikenai denda maksimum Rp 500.000.000,00 (lima ratus juta rupiah). Akan lebih baik jika seorang fotografer yang akan mengambil potret seseorang untuk dipromosikan, meminta izin potret atau meminta izin dari ahli waris terlebih dahulu.
\end{abstract}

Kata kunci: karya cipta potret, perlindungan hukum, undang-undang no 28 tahun 2014. 


\section{PENDAHULUAN}

Hak cipta adalah hak eksklusif pencipta yang timbul secara otomatis berdasarkan prinsip deklaratif setelah suatu ciptaan diwujudkan dalam bentuk nyata tanpa mengurangi pembatasan sesuai dengan ketentuan peraturan perundang-undangan.( Undang-undang Nomor 28 Tahun 2014 pasal 1 Ayat (1) )

Dan hak cipta merupakan hak eksklusif bagi pencipta untuk mengumumkan atau memperbanyak hasil ciptaannya dalam beberapa bidang seperti bidang ilmu pengetahuan, seni dan sastra terdiri dari buku, program komputer, ceramah, kuliah, pidato serta rekaman suara atau gambar pertunjukan seseorang. (Tim Lindsey,. Et. All., 2011: 6)

Tetapi, sering terjadi orang yang mengambil karya orang lain tanpa seizin penciptanya sehingga menimbulkan kerugian terhadap pencipta aslinya. Maka disinilah sang pencipta harus membuktikan hasil ciptaannya. Dan disinilah peran penting seorang yang harus mendaftarkan hasil ciptaannya sehingga bila terjadi kasus pencurian terhadap ciptaan sang pencipta dapat membuktikan hasil ciptaannya dengan bukti pendaftaran hak ciptanya tersebut.

Peran masyarakat sangat penting, karena banyak masyarakat yang tidak tahu bila suatu potret yang diambil tanpa seizin pihak yang di potret atau ahli warisnya akan menimbulkan akibat hukum. Apabila potret tersebut diambil untuk penggunaan secara komersial, penggadaan, pengumuman, pendistribusian, atau komunikasi atas potret tanpa seizin yang dipotret akan menimbulan kerugian terhadap orang yang dipotret dan sebaliknya akan menimbulkan keuntungan terhadap orang yang memotret.

Contoh kasus yang sering terjadi adalah kasus potret dari pernikahan seseorang. Potret dari pengantin sering sekali disalah gunakan oleh pihak photografer yang mana potret tersebut sering dijadikan promo untuk studio photonya tanpa persetujuan pihak pengantin tersebut sehingga menimbulkan kerugian terhadap orang yang ada di dalam potret tersebut. Sehingga pasangan pengantin tersebut melaporkan sang photografer karena memakai potret mereka tanpa seizin mereka dan photografer tersebut dikenakan pasal 115 undang-undang nomor 28 tahun 2014 yang mana sang photografer dipidana dengan pidana denda paling banyak sebesar Rp 500.000.00,00 (lima ratus juta rupiah).

\section{METODE PENELITIAN}

1. Metode

Metode yang dipakai dalam penelitian ini adalah penelitian yuridis normatif, karena penelitian hukum sejenis ini mengkonsepkan suatu penelitian yang tertulis didalam peraturan perundang-undangan, atau norma yang menjadi patokan perilaku manusia yang dianggap pantas. Soerjono Soekanto mengatakan bahwa penelitian hukum normatif adalah penelitian hukum yang dilakukan dengan meneliti bahan pustaka atau data sekunder belaka. Penelitian hukum normatif mencakup penelitian terhadap sistematika hukum, penelitian terhadap taraf sinkronisasi vertical dan horizontal, perbandingan hukum dan sejarah hukum. (Soerjono Soekanto dan Sri Mamudji, 199: 13).

\section{Sumber Bahan Hukum}

Sumber bahan hukum terbagi 3 (tiga) yaitu bahan hukum primer, 
sekunder dan tersier. Adapun penjelasannya sebagai berikut:

a. Bahan hukum primer, yaitu bahan hukum yang mengikat terdiri atas:

1. kitab undang-undang hukum perdata.

2. Undang-Undang No. 28 Tahun 2014 Tentang Hak Cipta.

b. Bahan hukum sekunder, yaitu bahan hukum yang memberikan penjelasan terhadap bahan hukum primer, yaitu:

1. Hasil penelitian pakar hukum tentang hak cipta.

2. Jurnal dan artiket tentang hak cipta.

c. Bahan hukum tersier, yaitu bahan hukum yang memberi petunjuk dan penjelasan terhadap bahan hukum primer dan sekunder, yaitu:

1. Kamus

2. Ensklopedia

3. Prosedur Pengumpulan Bahan Hukum.

Di dalam prosedur pengumpulan bahan hukum, penulis melakukan dengan cara mencari buku-buku dan literatur yang didapat baik melalui website ataupun manual yang terkait dengan masalah yang ada, baik berupa jurnal, majalah ilmiah, yang mendukung penyelesain masalah yang ada, kemudian dikumpulkan dengan cara membagi berdasarkan tema ataupun judul yang sama. Setelah dikumpulkan dan di seleksi baru kemudian penulis menganalisis bahan-bahan hukum yang ada.

\section{Analisis Bahan Hukum}

Menurut Amirudin dan Zainal Asikin bahwa dalam pengolaan dan analiss data pada peneliti hokum sosiologis, tunduk pada cara analisis data ilmu - ilmu sosial. Untuk menganalisis data, tergantung sungguh pada sifat data yang dikumpulkan oleh peneliti (tahap pengumpulan data). Jika sifat data yang dikumpulkan hanya sedikit, bersifat monografis atau berwujud kasus-kasus sehingga tidak dapat disusun ke dalam suatu struktur klasifikasi analisis yang di pakai adalah kualitatif. Jadi dalam hal ini penulis mengunakan analisis bahan hukum dengan metode kualitatif. (Amiruddin,dan Zainal Asikin, 2004, hlm. 167-168).

\section{HASIL dan PEMBAHASAN}

\section{Bentuk perlindungan hukum atas potret berdasarkan undang- undang nomor 28 tahun 2014 tentang Hak Cipta.}

Suatu potret atau foto yang dibuat seizin dari orang yang terdapat didalam potret, jika akan digunakan untuk kepentingan komersial, penggadaan, pengumuman, pendistribusian dan komunikasi atas potret akan lebih baik mendapat izin dari orang yang akan di potret atau ahli warisnya dalam jangka waktu 10 (sepuluh) tahun setelah orang yang dipotret telah meninggal dunia terlebih dahulu.

Suatu potret bila memuat gambar 2(dua) orang atau lebih maka harus terlebih dahulu meminta izin kepada masing-masing orang yang ada didalam potret tersebut, dan harus mendapatkan izin ahli waris masingmasing pihak dalam jangka waktu 10 (sepuluh) tahun setelah orang yang dipotret meninggal dunia terlebih dahulu. Apabila suatu potret tidak dapat izin dari pihak terkait itu dapat merugikan dirinya sendiri walaupun pemegang hak cipta potet tersebut adalah sang photografer. 
Didalam undang-undang hak cipta menjelaskan jenis-jenis ciptaan yang dilindungi sebagaimana diatur didalam penjelasan pasal 40 undangundang nomor 28 tahun 2014 tentang hak cipta adalah:

1. Yang dimaksud dengan "perwajahan karya tulis" adalah karya cipta yang lazim dikenal dengan "typholographical arrangement", yaitu aspek seni pada bentuk penulisan karya tulis. Hal ini mencangkup antara lain format, hiasan, komposisi warna dan susunan atau tata letak huruf indah yang secara keseluruhan menampilkan wujud yang khas.

2. Yang dimaksud "alat peraga" adalah ciptaan yang berbentuk 2 (dua) ataupun 3 (tiga) dimensi yang berkaitan dengan geografi, topografi, arsitektur, biologi, atau ilmu pengetahuan lain.

3. Yang dimaksud "lagu atau musik dengan atau tanpa teks" diartikan sebagai satu kesatuan karya cipta yang bersifat utuh.

4. Yang dimaksud dengan "gambar" adalah motif, diagram, seketsa, logo, unsur-unsur warna dan bentuk huruf indah. Sedangkan "kolase" adalah komposisi artistik yang dibuat dari berbagai bahan, misalnya kain, kertas, atau kayu yang ditempelkan pada permukaan sketsa atau media karya.

5. Yang dimaksud dengan "karya seni terapan" adalah karya seni rupa yang dibuat dengan menerapkans seni pada suatu produk sehingga memiliki kesan estetis dalam memenuhi kebutuhan praktis, antara lain penggunaan gambar, motif, atau ornamen pada suatu produk.

6. Yang dimaksud dengan "karya arsitektur" adalah wujud fisik bangunan, penataan letak bangunan, gambar rancangan bangunan, gambar teknis bangunan, dan model atau maket bangunan.

7. Yang dimaksud dengan " peta" adalah suatu gambaran dari unsur alam dan/atau buatan manusia yang berada diatas ataupun dibawah permukaan bumi yang digambarkan pada suatu bidang datar dengan skala tertentu, baik melalui media digital maupun non digital

8. Yang dimaksud dengan "karya seni batik" adalah motif batik kontemporer yang bersifat inovatif, masa kini, dan bukan tradisional. Karya seni tersebut dilindungi karna mempunyai nilai seni, baik dalam kaitanya dengan gambar, corak, maupun komposisi warna. Yang dimaksud dengan "karya seni motif lain" adalah motif yang merupakan kekayaan bangsa indonesia yang terdapat di berbagai daerah, seperti seni songket, motif tenun ikat, motif lapis, motif ulos, dan seni motif lain yang bersifat kontemporer, inovatif, dan terus dikembangkan.

9. Yang dimaksud dengan "karya fotografi" meliputi semua foto yang dihasilkan dengan menggunakan kamera

10. Yang dimaksud dengan "karya sinematografi" adalah ciptaan yang berupagambar bergerak (moving images) antara lain film dokumenter, film iklan, reportase atau film cerita yang dibuat dengan skenario, dan film kartun. Karya sinematografi dapat dibuat dalam pita seluloid, pita vidio, piringan vidio, cakram optik dan/atau media lain yang memungkinkan untuk dipertunjukan untuk dipertunjukan di bioskop, layar lebar, televisi, atau media lainnya. Sinematografi merupakan salah satu contoh audiovisual. 
11. Yang dimaksud dengan "bunga rampai" meliputi ciptaan dalam bentuk buku yang berisi kompilasi karya tulis pilihan, himpunan lagu pilihan, dan komposisi berbagai karya tari pilihan yang direkam dalam kaset, cakram optik, atau media lain. Yang dimaksud dengan " basis data" adalah kompilasi data dalam bentuk apapun yang dapat dibaca oleh komputer atau kompilasi dalam bentuk lain, yang karena alasan pemilihan atau pengaturan atas isi data itu merupakan kreasi intelektual. Pelindungan terhadap basis data diberikan dengan tidak mengurangi hak para pencipta atas ciptaan yang dimaksud dalam basis data tersebut.

Bentuk perlindungan terhadap karya cipta potret merupakan suatu kebijakan yang dibuat pemerintah untuk mencegah terjadinya kasus pengambilan potret orang lain tanpa persetujuan pihak yang dipotret yang tertera dalam undang-undang nomor 28 tahun 2014 tentang Hak Cipta. Walaupun dengan dibuatnya undang-undang tersebut masih saja ada orang atau photografer yang mengambil potret orang lain tanpa persetujuan untuk penggunaan secara komersial, penggadaan, pengumuman, pendistribusian, atau komunikasi atas potret tanpa seizin yang dipotret.

\section{Akibat Hukum Photografer Yang Mengambil Potret Orang Lain Tanpa Izin.}

Akibat hukum bagi photografer yang mengambil potert orang lain tanpa izin pihak terkait diupayakan penyelesain sengketanya melalui 2 (dua) alternatif sengketa yaitu arbitrase atau pegadilan.

\section{a. Arbitrase}

Sengketa Alternatif Arbitrese biasanya dipilih untuk menyelesaikan masalah dengan cara berdamai antara orang yang memotret dan pihak yang dipotret tanpa harus terjadi sengketa di pengadilan. Biasanya arbitrase dipilih karena dilakukan dengan cara berdamai antara pemotret dengan yang dipotret. Dan ini menempatkan agar penyelesain sengketa perdata itu dapat diselesaikan dengan cara cepat, murah dan biaya ringan sesuai dengan asas peradilan yang dianut oleh sistem peradilan perdata Indonesia.

\section{b. Pengadilan}

Bagi orang yang mengamil potret orang lain tanpa seizin pihak yan dipotret apa lagi menggunakan potret tersebut untuk keperluan promosi tanpa persetujuan pihak yang dipotret maka akan dikenakan pasal 115 UndangUndang nomor 28 tahun 2014 tentang hak cipta. Ia dikenakan pasal tersebut karena telah menggunakan potret orang lain tanpa seizin pihak yang diporet, Ia dipidana dengan denda pidana paling banyak sebesar $\mathrm{Rp}$ 500.000.000,00 (lima ratus juta rupiah).

\section{KESIMPULAN dan SARAN}

\section{Kesimpulan}

Bahwa kesimpulan yang didapat dari urain yang telah dipaparkan adalah:

1. Pemilik hak cipta potret menurut Undang-Undang Nomor 28 Tahun 2014 adalah orang yang termuat wajahnya dalam potret tersebut adalah pemegang hak cipta potret tersebut. sebuah potret apabila dibuat atas permintaan orang yang dipotret maka pemegang hak ciptanya adalah orang pribadi tersebut, tetapi apabila potret tersebut dibuat atas keinginan fotografer maka pemegang hak 
nya adalah sang fotografer tersebut tetapi apabila potret tersebut digunakan untuk penggunaan secara komersial, penggadaan, pengumuman, pendistribusian, atau komunikasi atas potret,

tanpa meminta izin terlebih dahulu maka photografer bisa dikenakan sanksi sesuai undang-undang nomor 28 tahun 2014.

2. Potret yang dibuat untuk pribadi tidak boleh digunakan oleh khalayak ramai karena hanya diperuntunkan untuk pribadi. Apabila sebuah potert digunakan untuk kepentingan lain, maka merugikan pihak yang dipotret sehingga hak moril dan hak ekonominya mengalami kerugian.

3. Akibat hukum dari photografer yang menggunakan foto seseorang tanpa izin adalah dengan dikenakan pidana dengan pidana denda paling banyak $\mathrm{Rp}$ 500.000.000,00 (lima ratus juta rupiah) sesuai dengan pasal 115 undang-undang no 28 tahun 2014 tentang hak cipta.

\section{Saran}

Saran yang akan diberikan adalah:

1. Perlunya Peran pemerintah untuk memberikan sanksi yang tegas kepada pelanggar hak cipta potret, kerena kurangnya sanksi yang tegas dari pemerintah sebuah karya cipta potret sering kali diambil dari sang pemegang hak cipta potret tanpa izin terlebih dahulu.

2. Perlunya sosialisai kepada masyarakat bahwa sebuah potret yang diambil tanpa seizin pihak terkait dapat menimbulkan kerugian pada pemilik potret dan ahli warisnya. Dan banyak juga masyarakat yang mengetahui bila potret nya diambil tanpa seizin nya tetapi tidak melaporkannya, meski ia tidak setuju bila potret tersebut dipublikasikan.

\section{DAFTAR PUSTAKA}

Buku

Amiruddin,dan Zainal Asikin,Pengantar Metode Penelitian Hukum, (Jakarta:PT Raja Grafindo Persada, 2004), hlm. 167-168.

Soekanto soerjono dan Sri Mamudji, Penelitian Hukum Normatif, (Jakarta : Rajawali press,1995), hlm. 13

Tim Lindsey,.et.all.,,Hak Kekayaan intelektual Suatu Pengantar, Bandung, P.T. Alumni, 2011.

\section{Peraturan Perundang-Undangan}

Undang-Undang Nomor 28 Tahun 2014 Tentang Hak Cipta. 